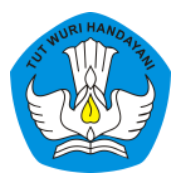

Page: 473-490

\title{
PENGEMBANGAN MEDIA KOPER PETUALANG BESUT UNTUK MENINGKATKAN MOTIVASI DAN HASIL BELAJAR SISWA
}

\author{
Wiwik Andriani \\ Sekolah Dasar Negeri Kepanjen 2 Jombang, Jawa Timur, Indonesia \\ Email:wi2k0809@gmail.com
}

Published: Jul 30, 2020

Article Url: https:/ / ojsdikdas.kemdikbud.go.id/index.php/didaktika/article/view/137

\begin{abstract}
Tujuan penelitian ini adalah untuk mengembangkan media pembelajaran koperetualang besut dan meningkatkan motivasi dan hasil belajar siswa. Metode yang digunakan dalam penelitian ini adalah penelitian dan pengembangan model ADDIE. Validasi instrumen pengumpul data dilakukan dengan tiga validator yang ahli di bidang media dan mencapai tingkat kevalidan rata-rata 92,31\%. Hasil penelitian menujukkan hasil belajar kompetensi pengetahuan mengalami peningkatan pada semua muatan pelajaran, rata-rata kompetensi pengetahuan sebelum menggunakan media PPKN 73 meningkat menjadi 93,57, Bahasa Indonesia 72,3 menjadi 93,75, IPA 76,9 menjadi 95,31, IPS 76,13 menjadi 96,75, SBDP 71 menjadi 90,5. Kompetensi keterampilan dalam menentukan unsur-unsur cerita fiksi dan menyanyikan lagu sesuai tempo juga mengalami peningkatan dibandingkan sebelum menggunakan media. Kesimpulannya Media Koper Petualang Besut dapat meningkatkan motivasi dan hasil belajar siswa. (DITERJEMAHKAN KE DL BHS INGGRIS).
\end{abstract}

Keywords: Media, Besut Adventurer's Suitcase, Motivation and Learning Outcomes 


\begin{abstract}
Abstrak
Tujuan penelitian ini adalah untuk mengembangkan media pembelajaran koperetualang besut dan meningkatkan motivasi dan hasil belajar siswa. Metode yang digunakan dalam penelitian ini adalah penelitian dan pengembangan model ADDIE. Validasi instrumen dilakukan dari tiga validator yang ahli di bidang media dan mencapai tingkat kevalidan rata-rata 92,31\%. Hasil penelitian menujukkan hasil belajar kompetensi pengetahuan mengalami peningkatan pada semua muatan pelajaran, rata-rata kompetensi pengetahuan sebelum menggunakan media PPKN 73 meningkat menjadi 93,57, Bahasa Indonesia 72,3 menjadi 93,75, IPA 76,9 menjadi 95,31, IPS 76,13 menjadi 96,75, SBDP 71 menjadi 90,5. Kompetensi keterampilan dalam menentukan unsur-unsur cerita fiksi dan menyanyikan lagu sesuai tempo juga mengalami peningkatan dibandingkan sebelum menggunakan media. Kesimpulannya Media Koper Petualang Besut dapat meningkatkan motivasi dan hasil belajar siswa.
\end{abstract}

Keywords: Media, Koper Petualang Besut, Motivasi dan Hasil Belajar

\title{
A. Pendahuluan
}

Suasana belajar yang aktif, inovatif, kreatif, efektif dan menyenangkan adalah suasana kegiatan pembelajaran yang diharapkan terjadi di sekolah. Dimana siswa ikut terlibat dalam setiap proses untuk memperoleh pengetahuan, keterampilan serta nilai sikap. Suasana belajar tersebut dapat diwujudkan jika siswa aktif dalam segala aktivitas pembelajaran di dalam kelas. Dalam suasana belajar dibutuhkan keterlibatan mental dan aktivitas dari dalam diri siswa sendiri (Suyono, Hariyanto, 2015:14). Artinya proses pembelajaran dikatakan bermakna jika pembelajaran tersebut terjadi untuk dan oleh siswa. Tanggung jawab belajar ada pada diri siswa, guru hanya sebagai fasilitator yang bertugas untuk mendorong terciptanya suasana belajar yang dapat memotivasi siswa untuk belajar sepanjang hayat.

Kenyataannya kegiatan pembelajaran di sekolah saat ini merupakan kegiatan yang membosankan, kegiatan yang tidak menyenangkan, pembelajar pasif menerima dan mengikuti perintah guru. Siswa hanya seperti boneka mainan guru. Hal seperti ini timbul bukan tanpa sebab, hal 
tersebut didasari oleh fakta kegiatan pembelajaran yang terjadi di sekolah selama ini sebagian besar didominasi oleh guru. Kondisi ini jelas bertentangan dengan kondisi ideal yang diharapkan terjadi pada proses pembelajaran.

Berdasarkan pengamatan yang dilakukan terhadap pembelajaran tematik kelas IVA di SDN Kepanjen 2 Jombang pada kegiatan pembelajaran tema 8 tentang Daerah Tempat Tinggalku subtema 1 tentang Lingkungan Tempat Tinggalku, suasana belajar yang berpusat pada siswa belum terlihat. Hal tersebut dapat di lihat dari aktifitas siswa di dalam kelas yang cenderung pasif. Ketika guru menerangkan, siswa terlihat ada yang sedang mengobrol, ada yang sedang membaca komik, ada yang sedang menggambar di bukunya, ada yang sedang memotong-motong penghapus, ada yang sedang melamun, dan ada yang saling melempar kertas.

Kondisi tersebut terjadi karena pembelajaran hanya terpusat pada guru, siswa hanya menjadi pendengar di dalam kelas, apalagi dalam satu kelas terdapat 40 siswa, yang terkadang suara guru kurang jelas terdengar oleh siswa. Penyebab lain menurut pengamatan peneliti karena tidak adanya media belajar yang dapat menarik perhatian dan membantu pemahaman materi oleh siswa. Hal ini berdampak pada tidak tercapainya KKM oleh siswa pada KD tema tersebut. Hal ini dapat diketahui dari hasil Lembar Kerja Siswa (LKS) Kompetensi Pengetahuan yang diberikan guru.

SDN Kepanjen 2 Jombang sudah menggunakan kurikulum 2013, Pembelajaran pada kurikulum 2013 termasuk pembelajaran tematik. Pembelajaran tematik adalah penyatuan sebuah konsep dari beberapa muatan pelajaran yang berbeda dengan tujuan agar anak dapat belajar lebih berarti (Majid,Abdul.2014:87). Pembelajaran yang hanya berpusat pada guru tentunya sangat bertentangan dengan Pembelajaran pada 
kurikulum 2013 yang menggunakan pendekatan saintifik atau pendekatan berbasis proses keilmuan.

Berdasarkan persoalan di atas, perlu adanya inovasi pembelajaran yang dapat memudahkan siswa dalam belajar memahami tema 8 tentang Daerah Tempat Tinggalku subtema 1 tentang Lingkungan Tempat Tinggalku. Selain itu, inovasi tersebut diharapkan dapat membuat siswa terjun dan aktif secara langsung dalam pembelajaran, dapat mengkongkritkan materi-materi abstrak secara nyata. Dapat membantu siswa dalam memahami semua KD dalam tema tersebut yang memuat 5 muatan pelajaran diataranya : PPKn, Bahasa Indonesia, IPA, IPS, dan SBK. Solusi yang tepat untuk menjawab permasalahan di atas adalah dengan menggunakan media pembelajaran "Koper Petualang Besut".

Media ini merupakan media yang berbentuk seperti koper, yang di dalamnya terdapat tiruan atau maket berupa gunung, suasana pedesaan, perkotaan dan pantai. Di setiap tempat tersebut terdapat miniatur-miniatur yang menunjukkan aktivitas-aktivitas kegiatan perekonomian di setiap tempatnya. Melalui penggunaan media Koper Petualang Besut ini, Siswa akan terlibat secara langsung dalam proses pembelajaran sehingga siswa akan lebih aktif, pembelajaran akan berpusat pada siswa. Siswa tidak perlu membayangkan materi-materi yang abstrak, karena untuk mencapai kompetensi dasar pada setiap mupel siswa dapat langsung mengamati serta mempraktekan pada media Koper Petualang Besut. Tampilan Media yang menarik dan unik akan menambah ketertarikan siswa dalam belajar. Dengan adanya inovasi pembelajaran ini diharapkan dapat meningkatkan motivasi dan hasil belajar siswa. 


\section{B. Metode}

Media pembelajaran Koper Petualang Besut ini dihasilkan melalui sebuah penelitian dan pengembangan sederhana (RED). Metodee yang digunakan adalah metode $\mathrm{R}$ and $\mathrm{D}$ dengan model $A D D I E$ yang memiliki 5 langkah pengembangan, yaitu: Analisis (Analysis), Desain (Design), Pengembangan (Development), Implementasi (Implementation), Evaluasi (Evaluation) (Mulyatiningsih, 2012:183).

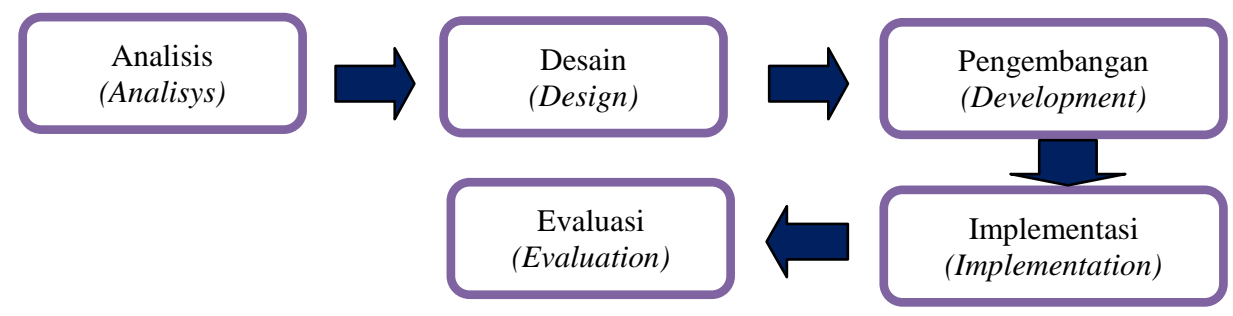

Gambar 3. Model pengembangan ADDIE (Mulyatiningsih, 2012:183)

\section{Prosedur Penelitian dan Pengembangan}

a. Analisis (Analysis)

\section{1) Analisis Kebutuhan}

Proses pembelajaran pada tema 8 Daerah tempat Tinggalku subtema 1 Lingkungan Tempat Tinggalku belum tersedia media pembelajaran yang sesuai dengan kompetensi dasar dan tujuan pada tema tersebut. Hal ini berakibat pembelajaran kurang efektif, siswa tidak semangat, dan pembelajaran monoton.

\section{2) Analisis Karakteristik Peserta Didik}

Karakteristik peserta didik kelas IVA SDN Kepanjen 2 Jombang unik mempunyai kemampuan belajar yang berbeda, cepat bosan, aktif dan kritis. 


\section{3) Analisis Kurikulum}

Kurikulum yang diterapkan di SDN Kepanjen 2 Jombang saat ini adalah Kurikulum 2013 yang menggunakan pendekatan tematikintegratif. Pada penelitian ini dipusatkan pada tema 8 Daerah Tempat Tinggalku, sub tema 1 Lingkungan Tempat Tinggalku, kelas IV dan memuat 5 muatan pelajaran yaitu PPKn, Bahasa Indonesia, IPA, IPS dan SBdP.

\section{b. Desain (Design)}

Pada tahap ini akan di desain media pembelajaran yang sesuai dengan hasil analisis sebelumnya, yaitu membuat Media koper Petualang Besut.

\section{c. Pengembangan (Development)}

Pada tahap ini, guru melakukan kegiatan diantaranya : (a) Membuat Rancangan perangkat pembelajaran RPP, (b) Memvalidasi media pembelajaran ke validator (c) Menyempurnakan Media pembelajaran yang telah dipilih.

\section{1) Membuat Rancangan Pelaksanaan Pembelajaran (RPP)}

Rencana Pelaksanaan Pembelajaran dibuat sebelum guru melaksanakan pembelajaran. RPP ini akan dilaksanakan di kelas IVA di SDN Kepanjen 2 Jombang, pada tema 8 Daerah Tempat Tinggalku, subtema 1 Lingkungan Tempat Tinggalku, muatan pelajaran PPKn, Bahasa Indonesia, IPA, IPS, dan SBdP.

\section{2) Memvalidasi Media Koper Petualang Besut ke Validator}

Sebelum menerapkan media pembelajaran Koper Petualang Besut pada proses pembelajaran peneliti melakukan proses validasi media 
pembelajaran dengan validator yang berkompeten dan paham tentang media pembelajaran serta penerapan kurikulum 2013.

Pada penelitian ini peneliti melakukan uji validasi pada validator praktisi dan validator akademisi. Uji validasi dilakukan dengan membawa media secara langsung kepada validator kemudian peneliti menjelaskan terkait bahan, cara pembuatan, keunikan, serta cara penggunaan media serta rencana pengaplikasian media ketika proses pembelajaran. Validator juga diberikan angket yang berisi 13 indikator pertanyaan terkait media koper petualang Besut, dalam angket tersebut juga terdapat tempat untuk memberikan saran atau masukan terkait media. Validator yang dipilih adalah a) Validator Praktisi yaitu 1. Bpk. Heri Mujiono, S.Pd. M.Pd dan 2. Bpk M. Janji Haryono, S.Pd. b) Validator akademisi yaitu Bpk. M. Farid Ubaidillah, M.Pd

\section{d. Implementasi (Implementation)}

Pada tahap implementasi atau penerapan ini dilakukan terbatas hanya pada sekolah tertentu. Implementasi ini bertujuan untuk mengetahui keefektifan penggunaan media Koper Petualang Besut yang dapat diketahui dari respon siswa. Implementasi dilakukan pada kelas IV A SDN Kepanjen 2 jombang Jl. KH. Wakhid Hasyim 97 Jombang Provinsi Jawa Timur pada semester genap tahun pelajaran 2018-2019 dengan jumlah siswa 40 orang.

\section{e. Evaluasi (Evaluation)}

Tahap Evaluasi (evaluation) merupakan tahap yang penting pada penelitian model ADDIE, karena pada tahap inilah kita dapat mengetahui keberhasilan dan keefektifan sebuah media pembelajaran pada proses pembelajaran. 
Ada beberapa langkah yang dilakukan peneliti untuk mengetahui kefektifan penggunaan media Koper Petualang Besut ini pada pembelajaran tema 8 subtema 1 kelas IV, diantaranya :

1) Untuk mengetahui kelayakan penggunaan media dengan memberikan angket respon kepada validator.

2) Untuk mengetahui peningkatan motivasi siswa selama pembelajaran peneliti melakukan pengamatan ketika kegiatan belajar mengajar berlangsung dan memberikan angket respon kepada siswa setelah kegiatan pembelajaran .

3) Untuk mengetahui peningkatan hasil belajar siswa yaitu untuk kompetensi pengetahuan dengan memberikan soal evaluasi yang diberikan sebelum pelaksanaan pembelajaran tanpa menggunakan media dan soal evaluasi yang sama setelah melakukan kegiatan pembelajaran dengan menggunakan media. Sedangkan untuk Kompetensi Keterampilan dengan menguji keterampilan siswa dalam menentukan unsur-unsur cerita fiksi dan kemampuan menyanyikan lagu sesuai tempo sebelum dan sesudah menggunakan media.

\section{f. Instrumen}

Untuk mengetahui tingkat kevalidan media diukur dengan memberikan angket kepada 3 orang validator yang ahli di bidang media. Untuk mengetahui motivasi belajar diukur dengan pengamatan yang dilakukan oeh guru selama proses pembelajaran berlangsung dan dengan memberikan angket respon kepada siswa. Instrumen untuk hasil belajar diperoleh dari untuk mengetahui kompetensi pengetahuan dengan memberikan soal yang dikerjakan siswa sebelum menggunakan media dan sesuda menggunaakan media. Instrumen untuk keterampilan siswa 
diperoleh dari: 1) Hasil keterampilan siswa menentukan unsur-unsur cerita fiksi dan mempresentasikannya. 2) Hasil keterampilan menyanyikan lagu sesuai tempo.

\section{Hasil dan Pembahasan}

\section{Hasil Validasi Media}

\begin{tabular}{|c|c|c|c|c|c|c|c|}
\hline \multirow{2}{*}{ No. } & \multirow{2}{*}{$\begin{array}{c}\text { Aspek } \\
\text { Nilai }\end{array}$} & \multirow{2}{*}{ Deskripsi } & \multicolumn{5}{|c|}{ Skala Nilai } \\
\hline & & & 1 & 2 & 3 & 4 & 5 \\
\hline \multirow[t]{5}{*}{1.} & \multirow[t]{5}{*}{$\begin{array}{l}\text { Tampilan } \\
\text { Umum }\end{array}$} & $\begin{array}{l}\text { Desain media sesuai dengan } \\
\text { materi pada tema } 8 \text { subtema } \\
1\end{array}$ & & & & & 3 \\
\hline & & $\begin{array}{l}\text { Desain media menggunakan } \\
\text { bahan yang ramah } \\
\text { lingkungan }\end{array}$ & & & & 2 & 1 \\
\hline & & $\begin{array}{l}\text { Biaya pembuatan media } \\
\text { relatif terjangkau }\end{array}$ & & & & 2 & 1 \\
\hline & & $\begin{array}{l}\text { Desain media menarik } \\
\text { dilihat }\end{array}$ & & & & & 3 \\
\hline & & $\begin{array}{l}\text { Desain media menyajikan } \\
\text { kenampakan alam di daerah } \\
\text { pegunungan, } \\
\text { pedesaan,perkotaan pantai } \\
\text { dengan jelas }\end{array}$ & & & & 2 & 1 \\
\hline \multirow[t]{2}{*}{2.} & \multirow[t]{2}{*}{$\begin{array}{l}\text { Tampilan } \\
\text { Khusus }\end{array}$} & $\begin{array}{l}\text { Pemilihan warna dalam } \\
\text { media }\end{array}$ & & & & 2 & 1 \\
\hline & & Pemilihan media yang unik & & & & & 3 \\
\hline
\end{tabular}




\begin{tabular}{|l|l|l|l|l|l|l|l|}
\hline 3. & $\begin{array}{l}\text { Penyajian } \\
\text { Media }\end{array}$ & $\begin{array}{l}\text { Tampilan media menarik } \\
\text { dan mudah } \\
\text { dibawa/dipindahkan }\end{array}$ & & & & & \\
& $\begin{array}{l}\text { Media awet, bisa disimpan } \\
\text { dan digunakan kembali }\end{array}$ & & & 3 \\
\hline & $\begin{array}{l}\text { Terdapat petunjuk } \\
\text { penggunaan media }\end{array}$ & & & 1 & 2 \\
\hline & $\begin{array}{l}\text { Terdapat petunjuk } \\
\text { perawatan media }\end{array}$ & & & 1 & 2 \\
\hline & $\begin{array}{l}\text { Penyajian data dapat } \\
\text { membantu siswa dalam } \\
\text { belajar (mengkonkritkan } \\
\text { pemikiran yang Abstrak) }\end{array}$ & & & 2 & 1 \\
\hline & $\begin{array}{l}\text { Penyajian media mampu } \\
\text { meningkatkan motivasi } \\
\text { belajar siswa }\end{array}$ & & & 2 & 1 \\
\hline
\end{tabular}

Dari table di atas diperoleh hasil skor persentase validasi sebagai berikut :

- Skor persentase validator $1=\frac{61}{65} \times 100 \%=93,85 \%$

- Skor persentase validator $2=\frac{60}{65} \times 100 \%=92,31 \%$

- Skor persentase validator $3==\frac{59}{65} \times 100 \%=90,76 \%$

- Skor persentase validasi keseluruhan $=\frac{93,85 \%+92,3196+90,76}{3}=92,31 \%$

Dari hasil tersebut terlihat bahwa skor validasi oleh 3 validator mencapai 92,31\% menunjukkan bahwa media Koper petualang Besut sangat valid digunakan dalam kegiatan pembelajaran. 


\section{Hasil Motivasi Belajar}

\section{a. Pengamatan}

\begin{tabular}{|c|l|c|c|}
\hline \multicolumn{1}{|c|}{ Rekap Hasil Pengamatan Selama Proses pembelajaran } \\
\hline No. & \multicolumn{1}{|c|}{ Aspek Pengamatan } & Skor Rata-Rata & $\begin{array}{c}\text { Konversi } \\
\text { Nilai }\end{array}$ \\
\hline 1. & $\begin{array}{l}\text { Keseriusan mendengar } \\
\text { penjelasan guru }\end{array}$ & 4,58 & 91,5 \\
\hline 2. & $\begin{array}{l}\text { Keaktifan bertanya dan } \\
\text { menjawab pertanyaan } \\
\text { guru }\end{array}$ & 4,65 & 93 \\
\hline 3. & $\begin{array}{l}\text { Sikap siswa saat ada } \\
\text { kelompok } \\
\text { presentasi/siswa nyanyi }\end{array}$ & 4,63 & 92,5 \\
\hline
\end{tabular}

Berdasarkan paparan data hasil pengamatan guru selama proses pembelajaran yang menunjukkan hasil sangat baik maka bisa dikatakan bahwa media Koper Petualang Besut dapat meningkatkan motivasi belajar siswa pada tema 8 subtema 1 .

\section{b. Hasil angket siswa}

Tabel 3.3 Hasil Rekapitulasi Angket Respon Siswa

\begin{tabular}{|c|c|c|c|c|c|c|c|}
\hline \multirow{2}{*}{ No } & Pertanyaan & \multicolumn{4}{|c|}{ Jawaban } & \multirow{2}{*}{$\%$} \\
\cline { 3 - 6 } & 1 & 2 & 3 & 4 & 5 & \\
\hline 1. & $\begin{array}{l}\text { Selama pembelajaran apakah } \\
\text { kamu merasa senang belajar } \\
\text { dengan menggunakan media }\end{array}$ & & & 2 & 15 & 23 & 90,5 \\
\hline
\end{tabular}




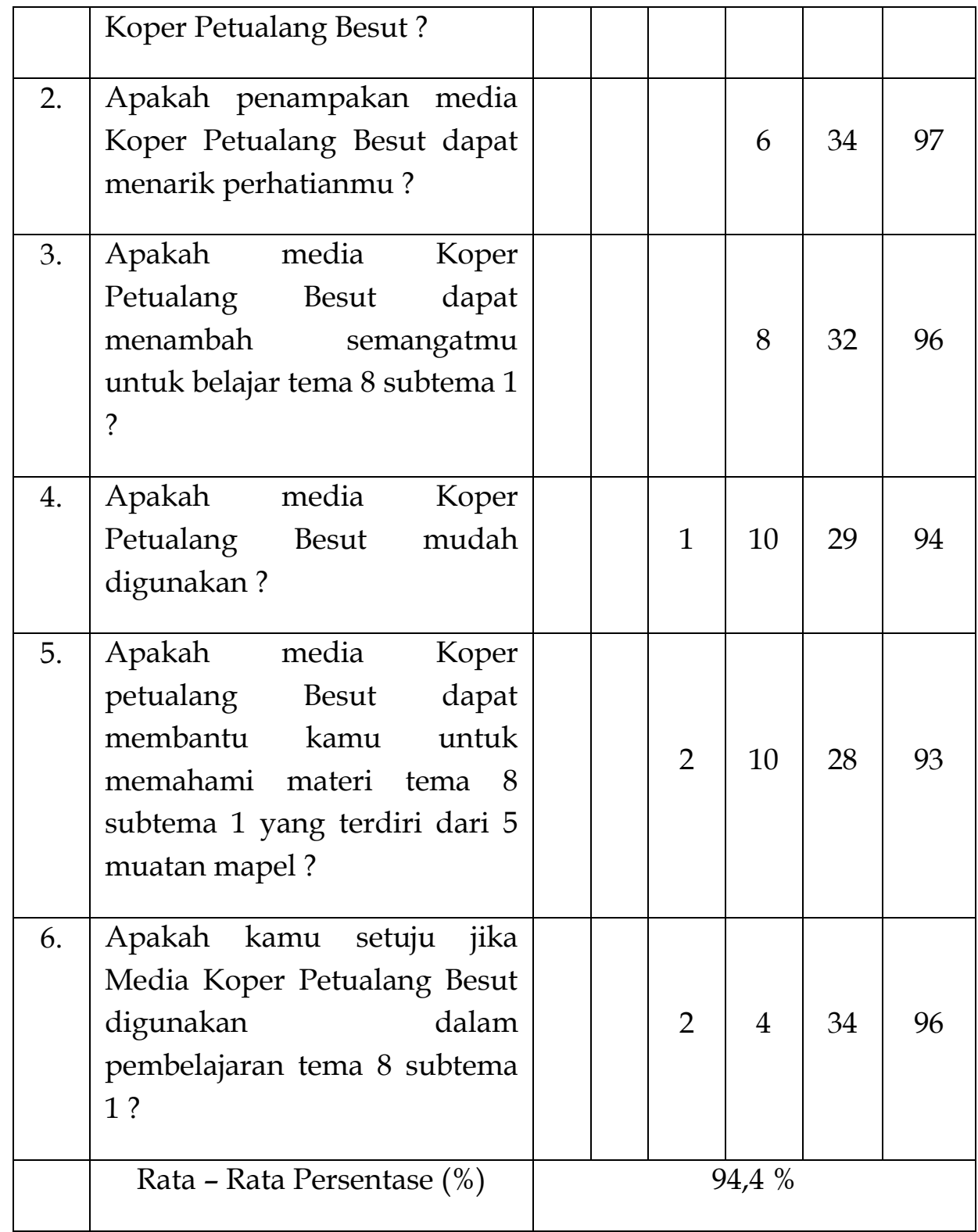

Berdasarkan hasil pengolahan angket respon siswa yang mencapai rata-rata $94,4 \%$ yaitu tergolong sangat baik maka dapat disimpulkan bahwa media Koper Petualang Besut dapat meningkatkan motivasi 
belajar siswa pada tema 8 Daerah tempat Tinggalku dan subtema 1 Lingkungan Tempat Tinggalku.

\section{Hasil Belajar Siswa}

\section{a. Hasil Nilai Kompetensi Pengetahuan}

Hasil Nilai Kompetensi Pengetahuan Sebelum menggunakan media dan sesudah menggunakan media

\begin{tabular}{|c|l|c|c|c|}
\hline \multirow{2}{*}{ No. } & \multirow{2}{*}{ Muatan Pelajaran } & \multicolumn{2}{|c|}{ Rata - Rata Nilai } & \multirow{2}{*}{ Ket. } \\
\cline { 3 - 4 } & & Sebelum & Sesudah & \\
\hline 1. & PPKN & 73 & 93,57 & Meningkat \\
\hline 2. & Bahasa Indonesia & 72,3 & 93,75 & Meningkat \\
\hline 3. & IPA & 76,9 & 95,31 & Meningkat \\
\hline 4. & IPS & 76,13 & 96,75 & Meningkat \\
\hline 5. & SBDP & 71 & 90,5 & Meningkat \\
\hline
\end{tabular}

Dari table di atas terlihat bahwa nilai semua muatan pelajaran sebelum menggunakan Media Koper Petualang Besut dan sesudah menggunakan mengalami peningkatan. Hal tersebut membuktikan bahwa penggunaan media Koper Petualang Besut dapat meningkatkan kompetensi pengetahuan siswa kelas IV SDN Kepanjen 2 pada tema 8 subtema 1.

\section{b. Hasil Nilai Keterampilan Menentukan Unsur-Unsur Cerita}

Nilai Keterampilan Menentukan Unsur Cerita Fiksi dan Presentasinya

\begin{tabular}{|c|c|c|c|c|}
\hline \multirow[t]{2}{*}{ No } & \multirow{2}{*}{ Aspek Pengamatan } & \multicolumn{2}{|c|}{$\begin{array}{c}\text { Rata - Rata Konversi } \\
\text { Nilai }\end{array}$} & \multirow[t]{2}{*}{ Ket. } \\
\hline & & Sebelum & Sesudah & \\
\hline 1. & $\begin{array}{l}\text { Kerjasama dalam } \\
\text { kelompok }\end{array}$ & 66,5 & 91,5 & Meningkat \\
\hline 2. & $\begin{array}{l}\text { Kesesuaian unsur-unsur } \\
\text { cerita dengan cerita yang } \\
\text { dibaca }\end{array}$ & 60 & 92 & Meningkat \\
\hline 3. & Kerapian, kejelasan peta & 62 & 86 & Meningkat \\
\hline
\end{tabular}




\begin{tabular}{|l|l|c|c|c|}
\hline & konsep & & & \\
\hline 4. & $\begin{array}{l}\text { Keterampilan ketika } \\
\text { presentasi di depan kelas }\end{array}$ & 64,5 & 88,5 & Meningkat \\
\hline
\end{tabular}

Berdasarkan table di atas terlihat bahwa pembelajaran menggunakan media Koper Petualang Besut mampu meningkatkan keterampilan peserta didik dalam menentukan unsur-unsur cerita fiksi serta mempresentasikan di depan kelas.

\section{c. Hasil Nilai Keterampilan Menyanyikan Lagu Sesuai dengan Tempo}

Hasil Nilai kompetensi Keterampilan Menyanyikan Lagu Sesuai tempo

\begin{tabular}{|c|l|c|c|c|}
\hline \multirow{2}{*}{$\begin{array}{c}\text { No } \\
\text {. }\end{array}$} & \multirow{2}{*}{ Aspek Pengamatan } & \multicolumn{2}{|c|}{$\begin{array}{c}\text { Rata - Rata } \\
\text { Konversi Nilai }\end{array}$} & \multirow{2}{*}{ Ket. } \\
\cline { 3 - 4 } & & Sebelum & Sesudah & \\
\hline 1. & Kesesuaian tempo & 64,5 & 88,5 & Meningkat \\
\hline 2. & Ekspresi & 68,5 & 85,5 & Meningkat \\
\hline 3. & Suara & 67,5 & 89 & Meningkat \\
\hline
\end{tabular}

Berdasarkan table di atas terlihat jika semua aspek penilaian yaitu kesesuaian tempo, ekspresi, suara dalam menyanyi mengalami peningkatan jika dibandingkan dengan sebelum menggunakan media.

\section{Penutup}

Berdasarkan hasil pelaksanaan kegiatan pembelajaran pada tema 8 Daerah Tempat Tinggalku subtema 1 Lingkungan Tempat Tinggalku yang dilaksanakan di kelas IV SDN Kepanjen 2 Jombang dengan menggunakan media Koper petualang Besut diperoleh kesimpulan sebagai berikut :

1. Media Koper Petualang Besut terbukti layak digunakan dalam pembelajaran tema 8 Daerah Tempat Tinggalku subtema 1 
Lingkungan tempat Tinggalku Kelas IV, hal ini dibuktikan dari hasil validasi oleh tiga validator ahli media yang mencapai nilai rata-rata 92,31 \% yang artinya media sangat valid untuk digunakan dalam kegiatan pembelajaran.

2. Media Koper Petualang Besut ini dapat meningkatkan motivasi siswa dalam pembelajaran tema 8 subtema 1 pada kelas IV hal ini terbukti dari hasil pengamatan guru selama kegiatan belajar mengajar berlangsung keseriusan siswa mendengar penjelasan guru mencapai 91,5\%, Keaktifan 93\%, serta sikap siswa saat ada kelompok atau siswa presentasi atau menyanyi mencapai 92,5\%. Selain dari hasil pengamatan guru, hasil pengolahan angket respon siswa setelah mengikuti kegiatan pembelajaran dengan menggunakan media Koper Petualang Besut mencapai 94,4\% termasuk dalam kategori sangat baik.

3. Penggunaan media Koper Petualang Besut terbukti dapat meningkatkan hasil belajar siswa pada materi tema 8 subtema 1 kelas IV. Hal ini dibuktikan dengan peningkatan rata-rata hasil belajar siswa pada kompetensi pengetahuan sebelum dan sesudah menggunakan media Koper Petualang Besut. Peningkatan ini pada semua muatan pelajaran yaitu PPKN, Bahasa Indonesia, IPA, IPS dan SBDP. Selain kompetensi pengetahuan peningkatan hasil belajar juga dapat dilihat dari peningkatan Kompetensi Keterampilan siswa yaitu dalam menentukan unsur-unsur cerita fiksi terlihat kerjasama kelompok, kesesuaian unsur-unsur cerita, kerapian penelitian peta konsep serta kemampuan presentasi mengalami peningkatan menjadi sangat baik. Sedangkan untuk keterampilan menyanyi juga 
mengalami peningkatan mulai dari kesesuaian tempo, ekspresi serta suara saat menyanyi.

\section{Ucapan Terima Kasih}

Artikel ini ditulis berdasarkan Naskah Perlombaan Karya Inovasi Pembelajaran Guru SD Tingkat Nasional Tahun 2018 atas bantuan dari Kesharlindung, Direktorat Guru dan Tenaga Kependidikan, Kemendikbud. Karena itu, saya sampaikan terima kasih kepada Direktoral GTK dan kepada editor jurnal Didaktika Pendidikan Dasar.

\section{Daftar Pustaka}

A.M, Sardiman.(2014). "Interaksi dan motivasi belajar-mengajar". Jakarta: PT Raja Grafindo Persada

Arifin Zainal.(2015). Evaluasi pembelajaran. Bandung: PT Remaja Rosdakarya

Arsyad Azhar. (2010). Media pembelajaran. Jakarta: PT Raja Grafindo Persada

Hartono.(2011). Pendidikan integratif. Purwokerto:STAIN Press.

Husamah,dkk. (2016). Belajar $\mathcal{E}$ pembelajaran. Malang : Universitas Muhammadiyah Malang

Majid, Abdul. (2014). Pembelajaran tematik terpadu. Bandung: Rosda

Mulyatiningsih, Endang. (2012). Metode Penelitian Terapan Bidang Pendidikan. Bandung: Alfabeta.

Nur, Cholifah. (2010). Pemanfaatan media maket untuk meningkatkan kemampuan berbicara siswa dalam memahami denah di kelas IV MI Miftahul Huda Dukuhsari Sukorejo Pasuruan. http:/ /library.um.ac.id/ptk/index.php?mod=detail\&id=46928.

Diunduh di Jombang, 30 April 2019

Riduwan. (2015). Skala pengukuran variabel - variabel penelitian. Bandung: Alfabeta. 
Romelah. (2017)."Model simulasi media maket dalam pembelajaran membaca denah siswa SMPN 1 punggelan, banjarnegara". Cendekia, 17.1978 2098.

Siswanto, R., Sugiono, S., \& Prasojo, L. (2018). The Development of Management Model Program of Vocational School Teacher Partnership with Business World and Industry Word (DUDI). Jurnal Ilmiah Peuradeun, 6(3), 365-384. doi:10.26811/ peuradeun.v6i3.322

Susilana, dan Riyana.(2014).Media pembelajaran. Bandung: CV Cwacana Prima

Suyono, dan Hariyanto.(2015). Belajar dan pembelajaran. Bandung: PT Remaja Rosdakarya

Winataputra,S U,dkk.(2016).Pembaruan dalam belajar di SD.Tangerang Selatan :Universitas Terbuka.

Worosetyaningsih, Tri. (2015). Upaya Meningkatkan hasil belajar IPS materi vulkanisme melalui media maket bubur kertas siswa kelas VII A SMPN 2 ngemplak semester 1 tahun pelajaran 2013/2014. https://journal.uny.ac.id/index.php/jipsindo/article/view/4523 .

Diunduh di Jombang, 21 April 2019

Yamin, Martinis.(2010). Kiat membelajarkan siswa. Jakarta: Gaung Persada Press.

Yusrizal, Y., \& Hanif, K. (2017). Increasing of Students' Motivation in Learning Physics Through the Use of Computer Simulation Media Viewed From Parents' Employment Background. Jurnal Ilmiah Peuradeun, 5(2), 201-212. doi:10.26811/peuradeun.v5i2.129 
Vol. 4, No. 2, Juli 2020 